\title{
沖縄軍用跡地の過剰開発プロセスにおける自治体の役割 \\ Role of the Local Governments in the Process of Overdevelopment of the US Military Base Sites in Okinawa
}

\author{
難波孝志 \\ Takashi NAMBA
}

This report considers redevelopment of the US military base sites which have not been focused on in any research. The statement regards that Okinawa may be overly developed; and the US base military sites may exceed the overdevelopment. This report focuses on the reason why the overdevelopment is triggered, and the roles that the Okinawa Prefecture and local governments play.

In 1972, Okinawa was returned to Japan by the United States, and Okinawa Development Finance has provided nearly ten trillion yen to Okinawa at present. Special Measures Law for Development of Okinawa had approved this financial endeavor, as the purpose of the law was to redress the economic gap with other regions in Japan.

After 1998, so called compensating development had started, which is the linkage of Okinawa's development and security regarding the military bases. However, to tell the truth, the division among Okinawa and other regions had been almost compensated in the 1990's. This political decision triggered the overdevelopment of public policy in Okinawa and the dependent economy of Okinawa toward the military bases.

2012 is a turning point of the exploitation of Okinawa military sites. Redevelopment of the US military base sites has additionally linked policy issues of bases and development of the region as compensation for the independence of the returned lands from the military bases. This policy has the potential to accelerate the overdevelopment. The main statement deals with the reality of ongoing redevelopment of the US military base sites and the role of the Okinawa Prefecture and local governments.

\section{1. 軍用跡地再開発への問題意識（沖縄過剩開発論の視点）}

本稿は、これまで研究対象とされることが少なかった沖縄の軍用跡地再開発を題材にし て、沖縄は過剰に開発されているのではないか、そして軍用跡地再開発は過剰開発をさら に加速させるのではないかという問題意識から、過剩開発はなぜ発生するのかについて、 特に沖縄県および沖縄地元市町村（自治体）の役割に焦点をあてて検討することを目的と する。 
沖縄県那覇空港に降り立ち、レンタカーを駆って本島内をドライブすると、沖縄の圧倒 的なインフラストラクチャー (ハード面の施設) の整備状況に瞠目する。これは、沖縄 3 大公共事業ともいわれる(1)道路・歩道整備、(2)護岸整備、(3)小中学校の校舎、校庭の整備 の 3 つの整備状況ゆえであるが、加えて、沖縄本島全域に広がる公共施設の数には驚かさ れる。例えば、北部地区だけを見ても、今回事例として取り上げる金武町の隣の宜野座村 では、ナイター設備・観客席を持つ野球場、サブグラウンド、ドーム型練習場を完備する。 ドームの建設だけで約 19 億円の公的資金が投入された。人口： 5,047 人、2012 年度歳入： 約 78 億円の村にである。同様に、本部町（人口：13,749人、2012 歳入：79億円）では、ナ イター設備のある全天候型陸上競技場が約 23 億円の資金を投じて建設されている。恩納 村（人口：10,435人、2012 歳入：80 億円）においては、北部振興事業（2001〜2005年）の 約 20 億円を、国頭村（人口：5,294人、2012歳入：58億円）においては、沖縄懇談会事業 （1999２003年）の約 27億円を投じて、ナイター設備のある全天候型グラウンドや野球場、 テニスコートなどが建設された（表 1 )。

北部地域に限つたことではない。これら同様の施設は、沖縄県内のほぼ全自治体に最低 1 か所以上は設置されているのである (図 1 、表 1 参照)。人口約 140 万人の沖縄県に、沖 縄本島だけで 16 もの野球場と 20 を超える陸上競技場、そして 11 のサッカー・ラグビー球 技場が必要であろうか。施設予約円滑化のために開設されているウェブページの予約状況 では、夏休みと 2 月のプロ野球キャンプの時期を除いて、これらの施設の利用頻度は極め て低い水準にある ${ }^{1)}$ 。これは、沖縄県の公共事業の手抜かりの無さであるが、他方で、沖 縄県民に対する欲求喚起の装置であって、日本政府による沖縄米軍基地に対するアメでも あったのだ。したがってここでは、過剰開発とは、自治体の人口や財政規模に比して、圧 倒的に高額な公共投資による事業が行われ、それらが適正に利用されていない状況を指す ことにしよう。

1972 年に本土復帰した沖縄県では、沖縄振興開発によって、現在までに約 10 兆円に近 い公的資金が投入されてきた。それは当初、沖縄振興開発特別法という総合計画によって 裏打ちされた。ここでいう総合計画とは、「戦後日本における国土の整備と振興策が全国 一律に行われ、地域間にインフラ整備や社会福祉・保健医療等の公共サービス、経済水準 や所得水準における格差を生まないこと」を目指すものであり、「『生活の質』の向上をそ のエッセンス」としている [青木, $2010: 95,102]$ 。したがって、復帰後の沖縄振興開発 計画は、琉球政府時代に島内のインフラ整備に関する独自の権限をほとんど奪われていた 沖縄県の社会資本整備の立ち遅れへの対応として始められた。第 2 次沖縄振興開発までの 重点的な開発の結果、1990年代に入ると、沖縄県のインフラ整備はほぼ本土並みの水準 に達した [重森, 2000：88-89]。

沖縄において、補償型政治論 [カルダー, 2008 : 199-211] の概念が登場してきたのは、 1998 年以降、特に第 3 次振興計画中に、沖縄振興、北部振興、島田懇 (沖縄懇談会 $)^{2)}$ に 


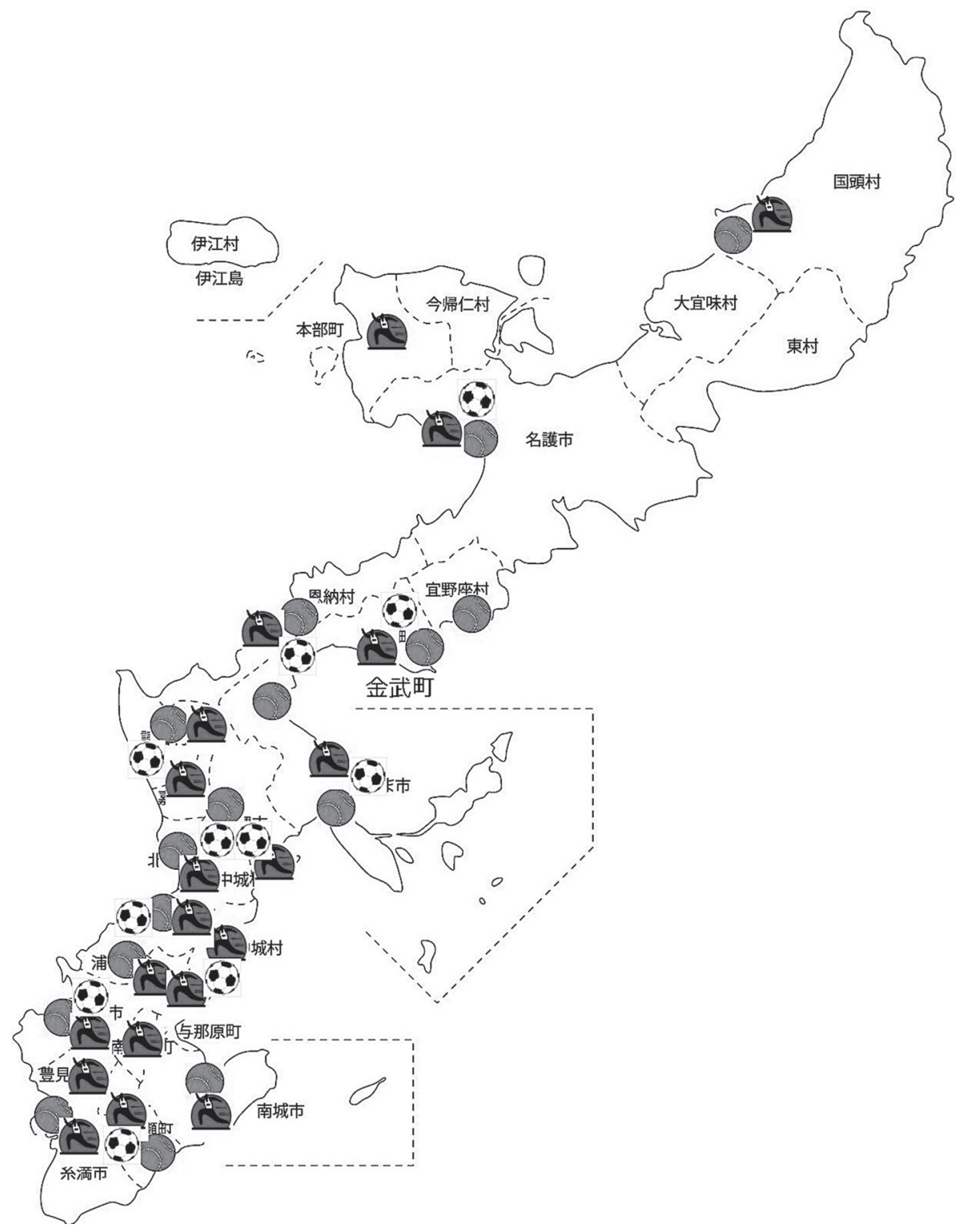

図 1 沖縄本島の野球場・陸上競技場

出典）各自治体WEBページから作成

よる公共事業（補償型沖縄振興）が行われるようになってからである。加えて、基地が所 在する自治体に対しては、基地交付金、調整交付金、周辺整備調整交付金、特別行動委員 会交付金、再編交付金等、自治体の歳入に対する各種の補助が行われてきた（表 1 )。い わゆる基地と沖縄振興のリンクである [島袋, 2014：24-26]。さらに2002年からは、「振 興開発」から「開発」の文字を抜いた沖縄振興特別措置法（第4次）の施行によって、更 
表 1 市町村基地関係収入（2012年度普通会計決算）

単位（千円）

\begin{tabular}{|c|c|c|c|c|c|c|c|c|c|c|}
\hline \multirow{2}{*}{\multicolumn{2}{|c|}{ 区分 }} & \multirow[b]{2}{*}{ 市町村 } & \multirow{2}{*}{\multicolumn{3}{|c|}{$\begin{array}{l}\text { 基地関係収 } \\
\text { 入合計 (島 } \\
\text { 田懇は含ま } \\
\text { ず)【A】 }\end{array}$}} & \multirow{2}{*}{$\begin{array}{l}\text { 歳入 } \\
\text { 総額に } \\
\text { 占める } \\
\text { 割合 } \\
(\mathrm{A} / \mathrm{B})\end{array}$} & \multirow[b]{2}{*}{$\begin{array}{c}\text { 歳入総額 } \\
\text { 【B】 }\end{array}$} & \multirow[b]{2}{*}{$\begin{array}{l}\text { 人口 (人) } \\
\text { 【C】 }\end{array}$} & \multirow[b]{2}{*}{$\mathrm{B} / \mathrm{C}$} & \multirow[b]{2}{*}{$\mathrm{A} / \mathrm{C}$} \\
\hline & & & & & & & & & & \\
\hline (2) & 1 & 那覇市 & 64,818 & 293,801 & 507,131 & $0.4 \%$ & $129,959,613$ & 316,138 & 411 & 2 \\
\hline 0 & 2 & 宜野湾市 & 209,942 & 532,764 & $1,068,774$ & $3.1 \%$ & $35,008,246$ & 92,467 & 379 & 12 \\
\hline 0 & 3 & 石垣市 & 0 & 300 & 300 & $0.0 \%$ & $23,160,081$ & 48,123 & 481 & 0 \\
\hline 0 & 4 & 浦添市 & 80,315 & 513,341 & 793,523 & $1.8 \%$ & $44,050,489$ & 111,463 & 395 & 7 \\
\hline (2) & 5 & 名護市 & 388,510 & 286,841 & $2,668,159$ & $7.9 \%$ & $33,681,451$ & 60,160 & 560 & 44 \\
\hline$\square$ & 6 & 糸満市 & 1,907 & 11,154 & 13,061 & $0.1 \%$ & $21,324,741$ & 58,799 & 363 & 0 \\
\hline \multirow[t]{2}{*}{ (2) } & 7 & 沖縄市 & $1,055,708$ & $1,332,980$ & $3,728,195$ & $6.7 \%$ & $55,269,998$ & 135,363 & 408 & 28 \\
\hline & 8 & 豊見城市 & 0 & 0 & 0 & $0.0 \%$ & $19,402,871$ & 57,957 & 335 & 0 \\
\hline (2) & 9 & うるま市 & 643,270 & 552,410 & $1,618,275$ & $3.3 \%$ & $49,208,954$ & 118,994 & 414 & 14 \\
\hline$\square$ & 10 & 宮古島市 & 0 & 14,687 & 14,687 & $0.0 \%$ & $37,906,804$ & 54,720 & 693 & 0 \\
\hline$\square$ & 11 & 南城市 & 9,009 & 13,499 & 22,508 & $0.1 \%$ & $19,728,705$ & 40,774 & 484 & 1 \\
\hline \multirow{2}{*}{ (2) } & 12 & 国頭村 & 134,853 & 50,967 & 233,167 & $4.0 \%$ & $5,852,003$ & 5,294 & 1,105 & 44 \\
\hline & 13 & 大宜味村 & 0 & 0 & 0 & $0.0 \%$ & $4,110,352$ & 3,398 & 1,210 & 0 \\
\hline \multirow{2}{*}{$\bigcirc$} & 14 & 東村 & 43,658 & 81,831 & 125,489 & $4.7 \%$ & $2,691,243$ & 1,946 & 1,383 & 64 \\
\hline & 15 & 今帰仁村 & 0 & 0 & 0 & $0.0 \%$ & $5,513,624$ & 9,518 & 579 & 0 \\
\hline (2) & 16 & 本部町 & 0 & 12,684 & 13,889 & $0.2 \%$ & $7,937,550$ & 13,749 & 577 & 1 \\
\hline (2) & 17 & 恩納村 & 923,900 & 50,749 & $2,692,534$ & $33.7 \%$ & $7,991,857$ & 10,435 & 766 & 258 \\
\hline 0 & 18 & 宜野座村 & 166,825 & 105,704 & $2,338,588$ & $30.0 \%$ & $7,798,297$ & 5,047 & 1,545 & 463 \\
\hline (2) & 19 & 金武町 & 224,584 & 516,009 & $2,777,420$ & $27.2 \%$ & $10,201,065$ & 11,215 & 910 & 248 \\
\hline 0 & 20 & 伊江村 & $1,173,295$ & 66,734 & $1,245,091$ & $17.6 \%$ & $7,073,512$ & 4,840 & 1,461 & 257 \\
\hline 0 & 21 & 読谷村 & 380,170 & 305,726 & $1,279,994$ & $9.3 \%$ & $13,814,566$ & 40,005 & 345 & 32 \\
\hline 0 & 22 & 嘉手納町 & 585,755 & 922,734 & $1,963,766$ & $22.8 \%$ & $8,598,538$ & 13,875 & 620 & 142 \\
\hline 0 & 23 & 北谷町 & 320,818 & 852,582 & $1,425,967$ & $10.1 \%$ & $14,170,688$ & 27,676 & 512 & 52 \\
\hline \multirow[t]{8}{*}{0} & 24 & 北中城村 & 51,122 & 305,726 & 397,480 & $6.6 \%$ & $5,989,934$ & 16,107 & 372 & 25 \\
\hline & 25 & 中城村 & 173,339 & 0 & 182,889 & $2.6 \%$ & $6,985,452$ & 17,639 & 396 & 10 \\
\hline & 26 & 西原町 & 0 & 0 & 12,495 & $0.1 \%$ & $12,895,469$ & 34,613 & 373 & 0 \\
\hline & 27 & 与那原町 & 0 & 0 & 0 & $0.0 \%$ & $7,763,207$ & 16,991 & 457 & 0 \\
\hline & 28 & 南風原町 & 0 & 0 & 0 & $0.0 \%$ & $12,796,082$ & 35,137 & 364 & 0 \\
\hline & 29 & 渡嘉敷村 & 0 & 0 & 0 & $0.0 \%$ & $1,726,709$ & 705 & 2,449 & 0 \\
\hline & 30 & 座間味村 & 0 & 0 & 0 & $0.0 \%$ & $1,809,766$ & 898 & 2,015 & 0 \\
\hline & 31 & 粟国村 & 0 & 0 & 0 & $0.0 \%$ & $1,845,166$ & 807 & 2,286 & 0 \\
\hline \multirow[t]{2}{*}{0} & 32 & 渡名喜村 & 76,872 & 300 & 92,020 & $8.0 \%$ & $1,153,613$ & 408 & 2,827 & 226 \\
\hline & 33 & 南大東村 & 0 & 0 & 0 & $0.0 \%$ & $4,365,498$ & 1,263 & 3,456 & 0 \\
\hline \multirow[t]{3}{*}{0} & 34 & 北大東村 & 0 & 0 & 0 & $0.0 \%$ & $3,590,203$ & 524 & 6,852 & 0 \\
\hline & 35 & 伊平屋村 & 0 & 0 & 0 & $0.0 \%$ & $2,463,020$ & 1,317 & 1,870 & 0 \\
\hline & 36 & 伊是名村 & 0 & 0 & 0 & $0.0 \%$ & $2,888,385$ & 1,591 & 1,815 & 0 \\
\hline (2) & 37 & 久米島町 & 238,677 & 15,336 & 273,322 & $3.6 \%$ & $7,502,998$ & 8,541 & 878 & 32 \\
\hline \multirow[t]{7}{*}{$\square$} & 38 & 八重瀬町 & 5,637 & 8,137 & 13,774 & $0.1 \%$ & $11,678,524$ & 27,679 & 422 & 0 \\
\hline & 39 & 多良間村 & 0 & 0 & 0 & $0.0 \%$ & $2,531,591$ & 1,303 & 1,943 & 0 \\
\hline & 40 & 竹富町 & 0 & 0 & 0 & $0.0 \%$ & $6,565,009$ & 3,923 & 1,673 & 0 \\
\hline & 41 & 与那国町 & 0 & 0 & 0 & $0.0 \%$ & $2,766,262$ & 1,581 & 1,750 & 0 \\
\hline & 都 & 市計 & $2,453,479$ & $3,551,777$ & $10,434,613$ & $2.2 \%$ & $468,701,953$ & $1,094,958$ & & \\
\hline & & 村計 & $4,499,505$ & $3,295,219$ & $15,067,885$ & $7.8 \%$ & $193,070,183$ & 318,025 & & \\
\hline & 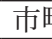 & 朾村計 & $6,952,984$ & $6,846,996$ & $25,502,498$ & $3.9 \%$ & $661,772,136$ & $1,412,983$ & & \\
\hline
\end{tabular}

○米軍基地及び自衛隊基地が所在する市町村

○米軍基地のみが所在する市町村

口自衛隊基地のみが所在する市町村

出典）『沖縄の米軍及び自衛隊基地（統計資料集）』平成 26 年 3 月 42 頁

人口：沖縄県 WEB ページ、市町村の人口・世帯数・面積（2012 年 8 月 9 日更新） 
なる公的資金の投入が図られる。すでに格差を是正するための開発は役目を終えたはずで あるが、基地と沖縄振興がリンクした補償型沖縄振興政策が開始される。このリンク政策 こそが、沖縄の公共施設に過剰な開発を引き起こしてきたのではなかろうか。想像してみ て欲しい。復帰前に歳出規模でほぼ同規模の本土の類似 5 県（島根・徳島・高知・佐賀・ 宮崎）それぞれに 16 の野球場と 20 を超える陸上競技場、そして 11 のサッカー・ラグビー 球技場がある姿を。そして皮肉にも、この時期には、全国の自治体が財政的あるいは行政 システムの合理化の観点から、市町村合併を進めていた。言うまでもないが、それは公共 事業の附けを負つた自治体の再編過程でもあつたのだ。現在なお、都道府県民 1 人あたり の公共事業費を指標として沖縄県への交付金は必ずしも多くないという批判もあるよう だ。しかし表 2 が示すように、沖縄県の 1 人あたりの公共機関からの公園・運動競技場施 設工事契約受注額は、資料が公表されるようになつた最近 3 年間だけを見ても、2015年に 国民体育大会開催予定の和歌山県に次ぐ位置にあり、2014年の国体開催地であつた長崎県 を凌ぐ勢いである。

2012 年、軍用跡地再開発にとつて大きな転換期が訪れる。基地と沖縄振興のリンクにさ らに加えて、軍用返還跡地再開発がそれらとリンクしたのである。今後 10 年間の沖縄振 興は返還跡地の再開発に注力される。そのやり方次第では、さらなる過剩開発が進行する 可能性が高い。なぜなら、これまでの沖縄振興策が、沖縄県や市町村などの地方自治体で はなくて、沖縄開発庁 (現在は内閣府沖縄総合事務局) という国家機関の主導で行われて きたからであり、こうした公共土木工事の展開そのものが自己目的化してきたからである [重森, 前掲：80］。そこで本稿では、現在進行中の軍用返還跡地再開発の現実と沖縄県お よび自治体の役割について検討する。

表 2 公園・運動競技場施設工事契約額(公共機関からの受注工事)

\begin{tabular}{|c|c|c|c|c|c|c|c|}
\hline \multirow[b]{2}{*}{ 順位 } & \multirow[b]{2}{*}{ 都道府県 } & \multicolumn{4}{|c|}{ 請負 契約額(百万円) } & \multirow{2}{*}{$\begin{array}{l}\text { 人口 (千人) } \\
2013 \text { 年 }(B)\end{array}$} & \multirow[b]{2}{*}{$\mathrm{A} / \mathrm{B}$} \\
\hline & & 2013年 & 2012年 & 2011年 & 3年計 (A) & & \\
\hline & 全国 & 323,571 & 233,477 & 175,912 & 732,959 & 127,083 & 5.77 \\
\hline 1 & 和歌山 & 9,525 & 5,129 & 8,935 & 23,589 & 971 & 24.29 \\
\hline 2 & 沖縄 & 8,682 & 4,871 & 5,825 & 19,378 & 1,421 & 13.64 \\
\hline 3 & 長崎 & 9,314 & 6,532 & 2,288 & 18,134 & 1,386 & 13.08 \\
\hline 4 & 福島 & 8,678 & 4,276 & 8,718 & 21,672 & 1,935 & 11.20 \\
\hline 5 & 新潟 & 7,441 & 8,884 & 9,502 & 25,827 & 2,313 & 11.17 \\
\hline 6 & 北海道 & 11,885 & 32,103 & 14,763 & 58,751 & 5,400 & 10.88 \\
\hline 7 & 長野 & 16,875 & 1,398 & 2,455 & 20,729 & 2,109 & 9.83 \\
\hline 8 & 愛媛 & 6,690 & 5,247 & 1,171 & 13,107 & 1,395 & 9.40 \\
\hline 9 & 山形 & 3,550 & 4,530 & 1,979 & 10,059 & 1,131 & 8.89 \\
\hline 10 & 佐賀 & 3,774 & 1,885 & 1,623 & 7,282 & 835 & 8.72 \\
\hline
\end{tabular}

註）e-Stat 国土交通省 建設工事受注動態統計調査 確報 公共機関からの受注 年度次 第19表 発注機関別、目的別工事分類別、施工都道府県別 から筆者作成 


\section{2. 軍用返還跡地再開発への自治体の関わり}

軍用返還跡地の再開発には、従前居住者が存在しない。本来ならば公的な補助を投入す ることなく、軍用地主が私的な財を投じて行うべきものである。従前居住者がいれば、そ の立ち退きが最大の問題となる。インナーシティに見られるジェントリフィケーション が注目されるのは、そこに階層的な社会変動が見られるから[難波, $2000 ： 91]$ あある。同 様に、再開発の問題も立ち退きによって地区住民の階層が入れ替わるから社会問題として 認識され、自治体が公的問題として関わる。なぜ従前居住者がいない軍用跡地再開発に自 治体が関与し、公的資金がつぎ込まれるのか。軍用返還跡地再開発に対する沖縄県および 自治体の果たす役割について、その研究意義は以下の 3 点にある。

第 1 点として、軍用跡地再開発は、沖縄の基地依存体質を変える方策として注目されて いることである。軍用跡地は、米軍基地の返還によって生み出される。その活用の在り方 が、補償型振興からの脱却と期待されるのである。この問題は、軍用跡地再開発への公的 資金投入の意義と関わる。返還された広大な土地群は、跡地だけの問題ではない。周辺地 域を含めた沖縄地域社会全体の問題なのだ。言いかえれば、跡地は軍用地主だけのもので はなくて、周辺に居住する地域住民の問題であって、そこに自治体の存在が重要となると いうわけである。例えば、那覇新都心牧港住宅地区や北中城村のアワセゴルフ場などで は、フェンスの向こうの世界、かつて自分の家や生活の糧となっていた農地があったとこ ろが、高級住宅地・ゴルフ場として米軍に使われていた。一般の人とは縁遠い存在であっ た軍用地が、返還されてもなお遠い存在である高級住宅地や高級リゾートホテルとして利 用される場合は、自治体の出る幕はないはずである。だが、地区住民の身近な存在として 公共施設やショッピングモールなどの商業施設になるとすれば、広大な面積の軍用跡地は 市民生活に直結した問題になるのである。そういつた意味では、通常「再開発」には「リ ニューアル」という訳語が与えられるが、軍用跡地再開発の場合「リディベロップメン 卜」と言つた方がよいであろう。軍用跡地再開発は、今なお総合計画の延長線上に位置づ けられ、実行し続けられているからである。

第 2 点は、軍用地主に対する土地活用のインセンティブを与える存在としての自治体の 役割である。補償型政治の仕組み導入以降においては、軍用跡地の利益装置化の問題があ る。具体的には国から軍用地に支払われる土地賃貸料 (以下、軍用地料) の問題である。 米軍による土地の強制的な接収以降、かつての土地所有者は生活の場を失いあるいは低水 準の地料に苦しんできた。「島ぐるみ土地闘争」以降、地料は徐々に引き上げられ、土地 を取られた人と取られなかつた人の立場が逆転するものさえ出てきた [来間, $2012: 67$ ]

加えて、1998年以降、軍用跡地利用に対する公的資金による補償が実施されるように なつた。その理由はこうである。「米軍に土地を強制的に接収され低額の軍用地料で苦し み土地返還を求めてきた軍用地主が、返還後に高騰した軍用地料に頼るようになり、生活 
のために土地返還に反対するようになってきた」「不安定な軍用地料に生活を依存するよ りも、跡地利用によって自立した生活を成り立つようにすることが望ましいことは言うま でもない」「そのためには、軍用地料依存から抜け出すためのクッションになる政策が必 要である。その一つが、返還地で収入が得られるようになるまでの補填措置としての給付 金制度である」[林, 2010：132]。軍用跡地は、返還されているのですでに軍用地ではな い。補償の必要はないはずだが、そこに公的な支援の必要性が生じると言うのである。

第 3 点は、都市再開発理論におけるアクター間の利害調整の必要性による自治体介入の 問題である。これは、長期的なスパンで、公共事業（公共性）のあり様を問う問題でもあ る。軍用跡地再開発に関わるアクターについては後述するが、ここではまず、軍用地主同 士の関係を考える。近隣の地価上昇は、自分の土地の地価上昇を生みだす。逆に、近隣の 地価が低い場合は、自分だけがその土地に投資しても地価が上がることはない。結果的 に、地主間の相互牽制が㗢き、近隣の地価上昇をお互いに待って再開発は進まない。これ を再開発における近隣効果 [難波, 2005：98-99］という。いわば再開発においては後出し 有利の法則が成り立つのである。そこに再開発における公的資金投入の必要性が生じる、 というのが再開発における公的資金投入の論理である。しかし、公的資金の投入には、逆 機能も存在する。すなわち、税金を投入するためには、アクター間の利害を調整し、「誰 にも損をさせない」構造を目指す（さなければならない）ことになるのである。

\section{3. 軍用跡地再開発アクター間の調整役としての自治体}

沖縄軍用跡地再開発関係アクター間の関連について、跡地再開発という特殊な事情の中 で、アクター間の調整役として重要な役割を果たす自治体を中心に整理しておこう。再開 発の現場では、以下6者のアクターが想定できる。

まず第 1 に、軍用跡地再開発の中心となるのは軍用地主である。沖縄県内に存在する米 軍・自衛隊基地の地主は、約 38,000 人 (2012 年 社団法人 沖縄県軍用地等地主会連合会 （以下、軍用地主会または土地連）加入者数）、また、国から支払われる軍用地料は、2012 年度、沖縄関係のみで年間約 959 億円 (防衛省所管 2012 年度 歳出概算要求書)に上る。こ れら軍用地主は、そのほとんどが個人であるが、中には（行政）区であったり、認可地縁 団体、郷友会であったりと地域住民組織である場合もある。今回は、分収金制度一つま り土地は市町村有であるが、実際には（行政）区がその管理・運用を行い、市町村から各 （行政）区へ軍用地料が配分される制度 [難波, 2013：27-28] —によって軍用地料を得て いる事例を紹介する。跡地再開発は、軍用地主が動かないと始まらないわけであるが、前 述の近隣効果の問題、そして、再開発後にそれまで得ていた軍用地料に見合うだけの収入 の確保が保証されることが前提となるため、思うようには進展しないのが現状である。

第 2 に、軍用地主会の存在である。軍用地主は直接、国 (防衛省) との交渉を行うわけ 
ではない。軍用地料の額を決めるのも、すべて軍用地主会が代表して行う。軍用地料の額 の交渉が国と行えるということは、裏を返せば日米安全保障や地位協定に直接関わるよう なことがらを背景に国との交渉を行うことができるということである。また、軍用地主会 は、軍用地主の金融機関的な役割も担うが、跡地再開発については、土地利用計画策定の ための自治体や地主・施行者との折衝、土地の先行取得・減歩率の交渉、地主への事業説 明、換地、地区計画の設定などの重要な作業を担う [真喜屋, $2010 ： 148$ 。

第3に、広域自治体である沖縄県である。県は 2012 年に「沖縄 21 世紀ビジョン基本計 画」を策定し、跡地利用そのものが 21 世紀ビジョン沖縄振興につながると位置付けた。 沖縄県の国に対するこの戦略は効を奏した。後述の一括交付金の創設によって、米軍と国 （防衛省）との交渉のもと返還順位が決まる軍用地の跡地利用についても、県が事業を指 定することで対処することが可能になったわけである。

第 4 のアクターは、国 (防衛省) である。国は、自治体に対して前述の各種交付金の交 付や沖縄振興、北部振興、島田稂等による公共事業によって、県を飛び越えて自治体ある いは地元（区）との太いパイプを持つ。また、跡地再開発に関する法的整備を行うのは国 である。跡地再開発に関する法的整備の交渉も、県や自治体との交渉が鍵となるのであ る。

第 5 のアクターは、民間コンサルタント、ディベロッパーである。もちろん、この 2 者 は利益のために再開発に参画するわけである。交渉がスムースに行えるように潤滑油の役 割を果たすが、利益が出ないとなると撤退も早い。大きな事業となると海外企業の参画も 増える。国境に近い地域の海外企業の土地買い占めなど、国内企業ではなかった事柄が露 呈することもある。

そして第 6 に、これらのアクター間の利害調整が可能で、跡地再開発の鍵を握るのが （市町村）自治体当局である。再開発後の地域計画図を画くのは自治体であり、進まない 跡地再開発を率先して動かしていくのも、軍用地主の利益優先型の再開発に対して歯止め をかけることができるのも自治体の役割である。

ここでは 6 者のアクターを想定したが、これらアクター間の、経済的のみならず、心理 的、社会的葛藤が完全に除去されたと自治体が判断した時に、初めて公的投資による軍用 跡地再開発は事業化され動き始めるのである。

\section{4. 軍用跡地利用にかかわる葛藤}

2013 年 8 月、内閣府沖縄総合事務局および沖縄県庁の担当課において、軍用跡地再開発 の概要、法的整備の状況等に関する聴き取りを行つた。その上で、内閣府沖縄総合事務局 ${ }^{4)}$ 総務部跡地利用対策課作成の「跡地カルテ」(2013 年 2 月) に記載されている軍用跡地のリ ストを手掛かりに、2014年 9 月まで 14 の各自治体の担当者から聴き取りを行った [難波, 
2015：5]。現段階では上述の 6 アクター間に、以下のような葛藤が存在することが明らか になってきた。

まず第 1 に、軍用地所有の有無にかかわる葛藤である。公的資金を投入した跡地再開発 が基地以外の地元商店を劦かす（パイの奪い合いになる）のである。軍用地主に対して、 その跡地利用事業に公的資金を投入することが、誰にも損をさせないルールから逸れるこ とになる。跡地再開発の成功事例と言われる那覇市牧港住宅地区跡地（新都心）や北谷町 (アメリカンビレッジ) においても、その懸念はすでに指摘されている [真喜屋, 2010 ： $161]$ 。

ただ、現在進行中の跡地再開発に対して、以下 3 つの批判が出てきている。1つめが、 ショッピングモールの誘致競争である。公的資金を使った巨大なショッピングモールの建 設には、他の地元商店を衰退させるという懸念が、いつもついてまわる。公的資金を使う からこそ、その懸念はなおさらである。2つめに、医療機関の移転問題である。跡地再開 発に伴う高度医療機関の他市町村への移転が問題になっている。大学病院や私立病院の移 転は、移転後の効率を重視するため、それらの建設場所をコントロールすることは難し い。3つめに、海外資本リゾート施設の誘致競争である。読谷村の旧ボローポイント射撃 場（飛行場）跡地や国頭村の旧VOA送信所跡地など、跡地再開発によってリゾートホテル が建設された例は珍しくない[沖縄タイムス社, $1997 ： 45-47,64-66$ ）が、公的資金を投じ た再開発によって海外資本を誘致し、それが既存のリゾートホテルへ影響を及ぼすことへ の懸念の声が少なからず聞かれた。まさに、ホテルの供給過剰というわけである。

第 2 に、返還順序による葛藤である。この葛藤はさらに 2 つタイプが考えられる。そ の 1 が、返還の前提条件としての返還順序である。SACO 最終報告や日米安全保障協議委 員会（２プラス 2 ）による返還合意には、返還条件として基地移転が含まれる場合が少な くない。注目を集める普天間飛行場跡地の返還は、名護市辺野古地区等への移転が条件で あるし、那覇港湾施設跡地は、浦添埠頭地区新規埋め立て地への移設等が条件になってい る。移設先では、受け入れを許可すれば恒久的な施設になってしまう可能性が高いので、 受け入れへの反発は大きい。その 2 は、単純に米軍からの返還順序の問題である。隣り 合つた基地の返還順序も葛藤を生むのである。道路を挟んで隣り合わせの返還跡地では、 返還順序を巡つて、自治体議会が反対決議を行つた事例もある。

第 3 に、返還是非への葛藤である。軍用地は返還されるべきか、返還されない方がいい か。全面返還ならよいが、一部返還なら拒否する。多くの跡地返還の事例は、小さな土地 が細切れに返還されてきたのである。跡地の返還が決まってからも、返還是非に関する葛 藤は存在する。また、沖縄夕イムスには、「沖縄の軍用地率を下げるのみ?いやがらせ？」 といつた記事まで掲載される [沖縄タイムス, 2013/9/8]。いわば、がけ地のような使い道 のない軍用地の返還は、米軍基地の沖縄集中のパーセンテージを下げるためだけのパ フォーマンスであって、返還される側には何のメリットもないというわけである。市当局 
が継続使用を要請した例もあり、また、嘉手納以北の山間部では、使い道のない土地はも ちろん、爆撃演習による不発弾や地雷が多数埋まっている土地を返還されても困るという 意見も出てくるのは当然であろう。正式な基地返還拒否を行った事例もある。

その他、再利用計画（自治体当局）と軍用地主の葛藤や基地反対運動による葛藤などが あるが、それらは別稿に譲る。

\section{5．軍用跡地利用における国・県・自治体の関係}

以上、 5 つの葛藤を見てきたが、これらアクター間の葛藤を除去するために、国、沖縄 県、各自治体において様々な計画が練られ工夫がなされてきた。2012 年の民主党政権によ る跡地利用特措法の制定と、沖縄振興一括交付金の交付という法的な措置は、今回のテー マである沖縄軍用跡地再開発にとっては、ひとつの岐路ともいうべきできごとであった。 ここでは、返還跡地再開発の法的経緯について、つまり沖縄県の戦略と国の対応について 辿つておこう。

本土復帰以前、沖縄県では軍用地として米軍に奪われた土地をめぐって「島ぐるみ土地 闘争」を展開する。1972年以降は、国に対して基地の整理縮小、本土との格差是正、本土 依存からの脱却、自立などの策を講じてきた。そして1995年以降、沖縄県はかつての戦争 と基地の存在への補償を沖縄振興計画に組み込んで、逆手に利用するようになる [瀧本・ 青木, 2014b：50]。1995年、村山政権下において「沖縄県における駐留軍用地の返還に伴 う特別措置に関する法律 (返還特措法または軍転特措法あるいは軍転法)」が施行され る。その契機は、那覇新都心地域の再開発であって、返還後の土地に対して軍用地料が支 払われるわけでもなく、一向に再開発が進まない軍用跡地に対して、利益を生みだすまで の間、軍用地料相当の補償をすべきであるという動きが発生し、県や地主会の意向を国が 認めたのである。

次に大きな変動を見せるのが、前述の 2002 年の「沖縄振興特別措置法」(第 4 次) の施行 である。この法の最も大きな改正点は、軍用跡地に対する国の財政支援の措置規定を盛り 込んだことである。すなわち、駐留軍用地跡地の利用の促進及び円滑化のための特別措置 を規定したのである。そして、返還特措法は 7 年の時限立法であったが、この法によって その期限を 2012 年まで延長した。返還特措法改正の大きな特徽は、大規模跡地と特定跡 地の 2 つのカテゴリーを設け、大規模な返還に対処（公有地への売却を促進）できるよう にしたこと、地主の補償を決めたことであった。返還後に利益を生み出せない地主に対し て、返還後 3 年間は、賃貸料相当の給付金を最大で 1 年間 1,000 万円、 3 年間で 3,000 万円 まで国が支払うことが決められた [沖縄県, $2013 ： 455-456$ ]。つまり、沖縄県は、戦争の 負の遺産を解消するための対象としたということのみならず、戦略として軍用跡地の活用 を始めたのである。ここに、先述の基地と沖縄振興のリンクに加えて、軍用跡地利用と沖 
縄振興のリンクの時代が到来したと解釈してもよいだろう。

そして 2012 年、民主党政権時代にまた大きな変動を見せるのである。返還特措法と沖 縄振興特別措置法の 2002 年追加された特別措置部分を、合体改正整備したのである。こ うして実現したのが「沖縄県における駐留軍用地跡地の有効かつ適切な利用の推進に関す る特別措置法 (跡地利用特措法)」である。この法改正の主な変更点は、跡地利用を国の責 任で行うことを明記したこと、返還後の支障除去措置を国が行うこと、大規模跡地と特定 跡地を一本化して拠点返還地にしたこと、軍用跡地を公有地として売却した者には5,000 万円までの特別控除を行うこと、返還日から支障除去の期間は利益を生まないので、支障 除去が終わつて引渡日から 3 年間へ給付期間が改められたことなどの点である。つまり、 跡地利用には国が責任を持ってさらに財政支援を行い、返還後一定期間軍用地主の生活の 安定を保障したのである [難波, $2015: 3-4]$ 。

もうひとつの民主党政権下での大変動は、2012 年の第 5 次ともいえる「沖縄 21 世紀ビ ジョン基本計画（沖縄振興計画）」の中において、交付金の国からのひも付きを廃止し、 より自由度の高いものとして、沖縄振興特別推進交付金と公共投資交付金からなる沖縄振 興一括交付金を創設したことであった。沖縄振興計画予算は概ね年間約 3,000 億円で、こ れまですべての交付金が国の意向を反映する形で配分されてきたのであるが、その半分を 沖縄県の自由裁量に任せることにしたのである。これは地方自治にとつて画期的なできご とであった [瀧本・青木, $2014:$ 64-67]。沖縄県は、公共事業のためのさらなる用地確保 が可能になったばかりか、各自治体にこの交付金を配分する権限を持つたことによって、 軍用跡地利用についても圧倒的な主導力を発揮することが可能になつたのである。

\section{6. ギンバル訓練場跡地（金武町）利用の事例}

第 4 節では、軍用跡地再開発をめぐるアクター間の葛藤を整理した。本節では特に、上 述のような沖縄県内の野球場や陸上競技場の実態をよそに、2011年に野球場を建設し、さ らにサッカー場の建設を進める金武町の「ギンバル訓練場跡地」利用の事例を詳細に見て いくことにしよう。2012 年 8 月および 2013 年 8 月から 9 月にかけて、金武町当局およびこ の跡地の地主が多く住む並里区の区長への聴き取りを行った。

金武町（人口：11,468人、 5,150 世帯：2015/1現在）は、沖縄本島中部に位置し、その人 口は増加傾向にある。沖縄本島内では 27 自治体中 20 番目の人口規模である。金武町の面 積は3,788haであり、うち米軍基地面積は2,184.3ha、基地比率 : 57.7\%（2013/10現在）に 上る。自治体面積に占める米軍基地面積の比率は、嘉手納町に次いで2番目に高い。町の

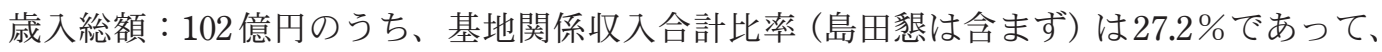
恩納村、宜野座村に次いで 3 番目に高い (表 1 参照)。また、金武町には、金武、並里、伊 芸、屋嘉、中川の 5 つの (行政) 区 ${ }^{5)}$ があつて、中川区以外には入会管理団体が組織され 
る。中川区は1946年に並里区から分離独立した区であって、いわゆる寄留民（かつての土 地所有者以外の人々 : 新規来住者) が多いと言われる。中川区には分収金による軍用地料 の配分はないのである（ただし金武町から区に対する補助が行われているが、他区からの 町費補助に対する批判も存在する)。

金武町内には、現在 3 つの米軍基地が存在する。名護市・恩納村・宜野座村にまたがる 「キャンプ・ハンセン」面積：21,448 (国有：994、県有：59、町有：14,507、民有：5,887) $\left(千 \mathrm{~m}^{2}\right)$ 、「金武レッド・ビーチ訓練場」面積 : 14 (国有 $: 1$ 、県有 : 一、町有 $: 0$ 、民有 : 13） $\left(千 \mathrm{~m}^{2}\right.$ )、「金武ブルー・ビーチ訓練場」面積 : 381（国有 : 53 、県有 $: 1$ 、町有 $: 1$ 、 民有：326）(千 $\mathrm{m}^{2}$ ） [沖縄県 2014.3 沖縄の米軍基地及び自衛隊基地（統計資料集）から］ の 3 つである。今回、跡地再開発が行われている「ギンバル訓練場跡地」面積602（国 有：一、県有：一、町有 $: 397$ 、民有 $: 205)\left(千 \mathrm{~m}^{2}\right)$ は、中川区に位置するが、その 6 割 $\left(\right.$ 約 340 千 $\left.\mathrm{m}^{2}\right)$ が並里区の区有地であった。ブルー・ビーチは並里区により近い場所に位 置する。

並里区は、人口 2,750 人、1,175世帯 $(2015 / 1$ 現在) で、金武町では金武区に次いで 2 番 目に大きい (行政) 区である。区の年間予算は、区有地による軍用地料収入もあって、1 億 3,700 万円 (2013年度) に上る。町内会の年間予算がこの額だと考えれば、その予算規 模の大きさが想像できるであろう。軍用地になった区有地からの収入が 8,000 万円、町か ら 3,200万円、事務委託料が 780 万円、その他利息収入などである。並里区には、並里区 行政条例という自治体の条例と同じような規程があって、区の行政が運営されている。選

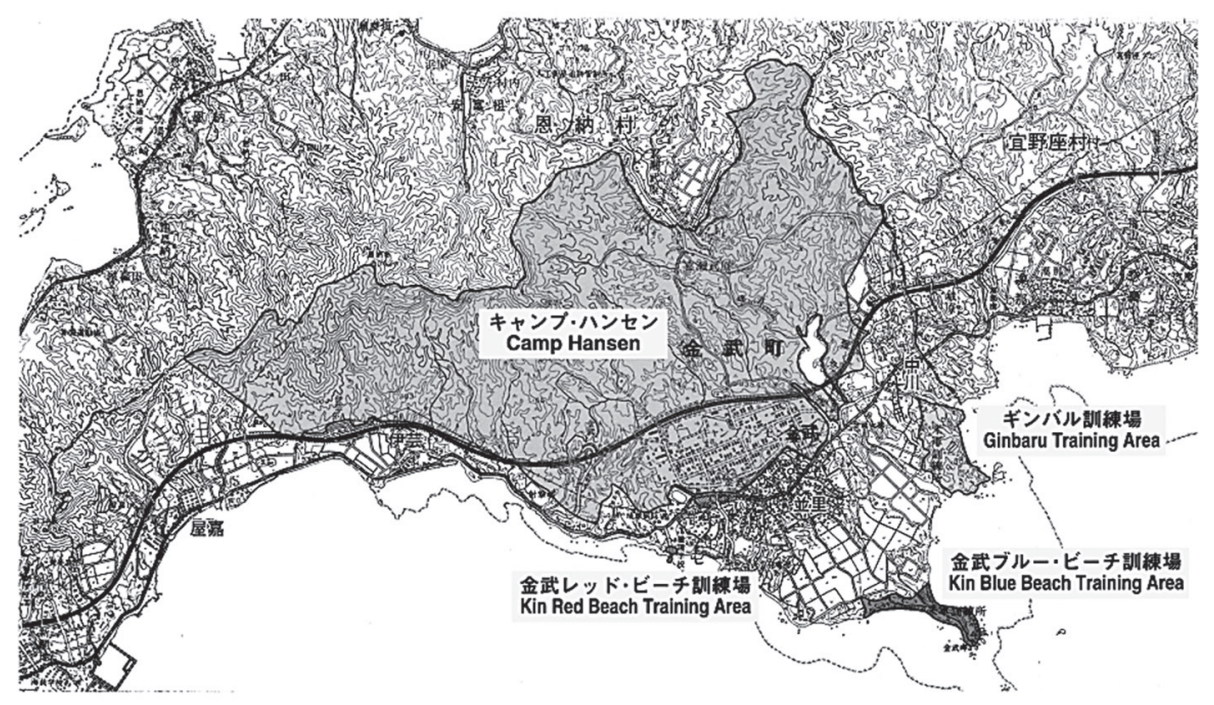

図 2 金武町の軍用地 出典）沖縄県金武町「金武町と基地」2002.10 
挙によって選出される区長をはじめ、12人を定数とする区議会も置かれる。財産管理会と 呼ばれる入会管理団体も組織されている。財産管理会は、いわゆる入会地であった杣山か らの分収金収入を管理する団体であるが、こちらの年間予算は 2012 年度で 2 億 6,199 万円 である。区と財産管理団体の関係については別稿に譲るが、並里区は他の区や宜野座村な どと違い 2 者が別になっていて、区内に住む住民全員が区有地からの収入に関しては享受 できる仕組みを確立している[難波, 2013]。

金武町の軍用地接収の過程は、少し特異であつた。1945年、沖縄本島西海岸の読谷山・ 北谷に上陸した米軍は、5 日後には東海岸の金武村・久志村一帯を制圧し、字金武の北 側、池原一帯にブルドーザや工作機械を持ち込んで、わずか 10 日間で飛行場を建設し た。日本の降伏によって金武飛行場は不要となり、なかば放置されるが、1947年、村に対 し「飛行場を射撃場に使用する」という通知がなされ、射撃演習が開始される。山林の活 用もできず、事故が多発し危険なだけで経済的なメリットが何もないことに苦悩する。 1956 年、米軍は辺野古の地主と新規接収について借地契約を結び、久志・辺野古の原野は 基地となり、歓楽街も出現した。「金武には弾は落ちるが、ドルは落ちない」「演習は金武 でやり、遊興は辺野古とコザ。軍用トラックの往来で子どもたちの通学も危険」「土地を 守る四原則はどうする」、金武村議会での議論は尽きなかった。ここに基地受け入れにお ける金武の大きな葛藤が出現する。この時大きな役割を果たしたのが部落常会 (今でいう 住民総会：筆者注）であった。「幾度も開かれた部落常会で衆議を尽くした」結果、苦渋 に満ちた決断として「新規接収を受け入れ基地を誘致すること」を決める。こうして金 武・宜野座にキャンプ・ハンセン、ギンバル訓練場など、フェンスで囲むことによって本 格的な米軍基地が建設されることになつたのである。1956年からの「島ぐるみ土地闘争」 も、軍用地料の引き上げを勝ち取り、終息へと向かった [沖縄県金武町, 1991 : 24-26, 32-33]。記録上からは、基地受け入れについては、村議会は地元の意向を尊重したという ように読み取ることができよう。ギンバル訓練場は、1958年金武村による米軍基地誘致後 に使用が開始される。その後の金武町のキャンプ・ハンセンゲート前の繁華街などの発 展、そして町の歳入総額の 3 割近くを占める基地関連の交付金など、基地依存体質へと変 容していくのである。

1996 年、ギンバル訓練場はSACO 最終報告において返還が合意される。1999年、金武町 は、ふるさとづくり・整備事業基本構想・全体計画調査を実施。2008年、日米合同委員会 において返還が合意され、2011年、全面返還。（返還された土地のうち約 230 千 $\mathrm{m}^{2}$ が返還 と同時に地主に引き渡され、残りの部分については既存施設の撤去後に引き渡される予 定。） 2012 年、 2 次引き渡し分（約 260 千 $\mathrm{m}^{2}$ ) が地主に引き渡された [跡地カルテから]。

$\mathrm{SACO}$ 最終報告では、ヘリコプター着陸帯 (ヘリパッド : $30 \mathrm{~m} \times 30 \mathrm{~m}$ のリココフターの ランディング・マット) をブルー・ビーチへ、泥土除去施設と消火訓練施設をキャンプ・ ハンセンへ移設すれば、翌年までに返還されることが合意されていた。まず、名護市・恩 
納村・宜野座村などの他市町村はギンバル訓練場の代替地候補となることに懸念を表明す る。そして、ここに町内の葛藤が生じる。特に並里区は「ブルー・ビーチは、ギンバルよ り並里区に近い位置にあり、なんら問題解決にならない。米軍車両の往来やへリ騒音など による環境悪化を懸念、返還要望の強いブルー・ビーチより、ギンバルの返還合意が先行 していることは地元無視で、これまでの町民、区民の努力を踏みにじるものと反発」する [琉球新報, 1996/12/10］。他方、中川区は「ギンバル訓練場が返還されずにそのまま利用 されることには反対」であり、「跡地利用計画を金武町全体の事業として早く進めてほし い」[沖縄タイムス, 2007/4/25]と主張する。並里区は1996年と2006年に反対の決議を行 い、金武町議会もこれらの施設をキャンプ・ハンセンやブルー・ビーチに移すことは、そ れらの施設の返還が遠のき基地強化になるとして、移設反対の立場をとる。

2007 年、これらの問題に終止符を打つたのは金武町長の決断だつた。町の活性化のため に、移設条件を飲むことを発表する。これに対して、並里区が行ったアンケートでは区民 の約66\%が反対の立場をとる [沖縄タイムス, 2008/5/14] が、結果的に町の活性化に協力し ようと地権者の 98\%が賛成したのである [難波, $2015: 13-14]$ 。ギンバル訓練場跡地事業 （金武町ふるさとづくり整備事業）は、最後の島田懇事業であった。沖縄全体で総事業費 1,000 億円と言われる島田懇事業のうち約 100 億円が金武町に配分され、その 4 分の 3 の約 75 億円がこの事業に投入された [難波, $2015: 14$ ]。もちろん、町当局と那覇防衛施設局に

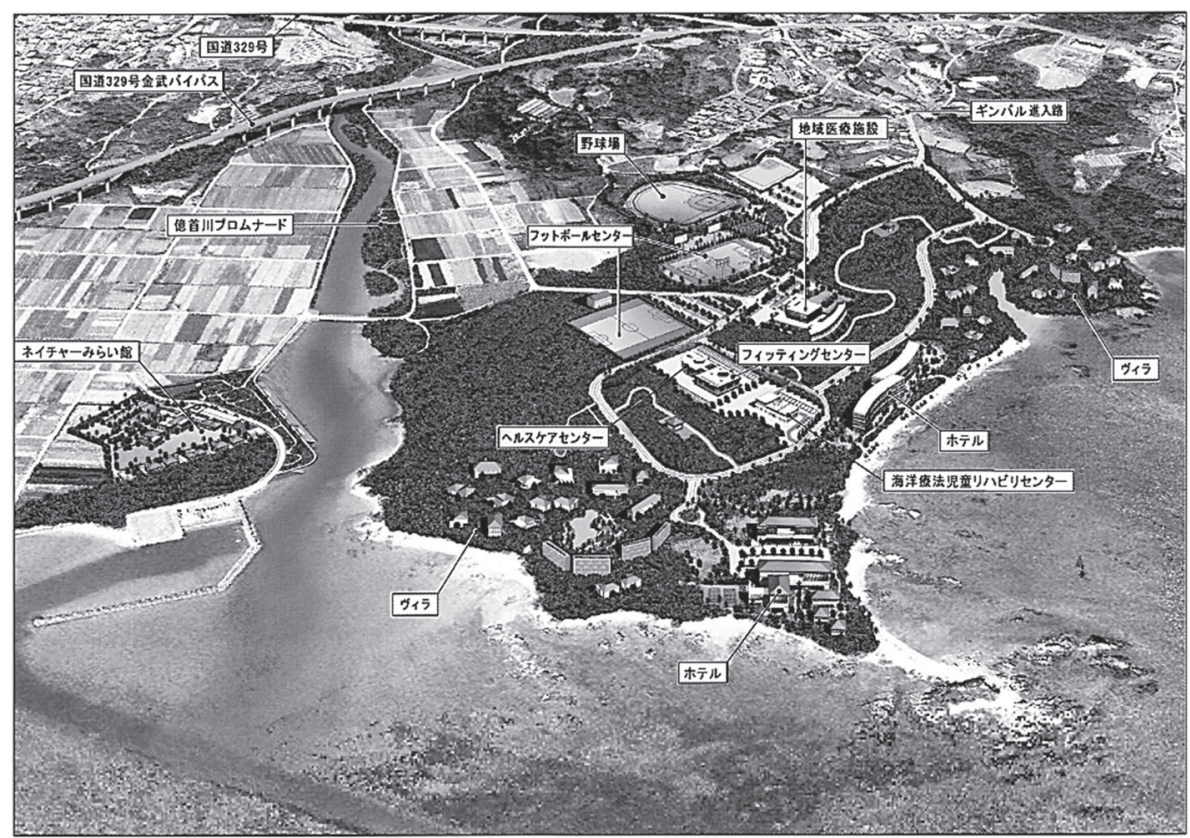

図 3 金武町ふるさとづくり整備事業概念図 出典）「広報金武」 特別号外 2012.11 
よる住民への説明会による説得によるところも大きいが、この機を逃さない、という金武 町の決断だったのである。

2011年、ギンバル訓練場跡地再開発に先駆けて、この土地の隣接地に北部振興対策事業 の約 16 億円（表 3 参照）を活用した「金武町ベースボールスタジアム」が完成する。広報 金武No.519 (2012/2) では、「観客 2 千人が収容できる待望の野球場ついに落成」と報じて いる。このスタジアムの建設計画段階において、他の自治体にあるものが、金武町にない 状態であるので、建設についての疑問の声は全くなかつたという。むしろ、町の広報も待 望という言葉で表現しているように、ホテル、リハビリ・センター、病院完備の、阪神夕 イガースキャンプで賑わう隣の宜野座村などとは差異化した野球場の建設を待ち望んでい たのである。

この後ギンバル訓練場跡地再開発では、 5 つの開発工区に分けて整備を予定している。 5つ星クラスのホテル・海外ブランドのスパリゾートホテル・戸建て住宅・マンション、 町特産の農水産物の販売を促進するための複合型商業施設・結婚式場・会議場・マリンス ポーツ施設、飲食店などである。また、島田懇を活用したふるさとづくり整備事業によつ ては、(1)道路、(2)地域医療施設、(3)ルスケア・センター、(4)リハビリ・センターの4つ の施設を建設した。県内トップクラスの癌の放射線治療や少しリッチな感覚で受けられる 人間ドックなどの設備を用意する。ホテルについては、マレーシアの開発会社と契約、高 級リゾートホテルを運営する予定である。

野球場以外に、約 11 億円の建設費（表 3 参照）をかけて 2014 年から建設中のフットボー ルセンターは、日本サッカー協会が望む芝の種類、土の固さ、砂の構造、水分の状態で設 計を行えることができたならば、J1チームや日本代表チームの合宿所として活用される 予定であるという。選手はグラウンドに隣接したホテルに宿泊でき、練習中にケガをして

表 3 ギンバル訓練場跡地利用計画事業費内訳 単位：千円

\begin{tabular}{|c|c|c|c|}
\hline & 平成23年度まで & 平成24年度以降 & 合 計 \\
\hline 島田懇談会事業 & $2,490,228$ & $5,064,271$ & $7,554,499$ \\
\hline 野球場（北部振興策事業） & 959,177 & 693,752 & $1,652,929$ \\
\hline $\begin{array}{ll}\text { フットボールセンター } & \begin{array}{c}\text { (沖縄北部連携促進特別 } \\
\text { 振興対策特定開発事業) }\end{array} \\
\end{array}$ & 0 & $1,158,225$ & $1,158,225$ \\
\hline 進入路道路整備 & 1,492 & 337,613 & 339,105 \\
\hline 人工ビーチ & 23,161 & $2,127,224$ & $2,150,385$ \\
\hline 温泉センター、公園、モニュメント、管理用道路 & 2,448 & $2,227,291$ & $2,229,739$ \\
\hline 合 & $3,476,506$ & $11,608,376$ & $15,084,882$ \\
\hline
\end{tabular}

出典）「広報金武」特別号外 2012.11 
も医療施設で治療が可能である。気候がよく、練習・宿泊・治療すべてが揃つている場所 は国内でも少ないという [南, $2014: 68$ ]。しかし、この施設は沖縄本島内 11 番目のサッ カー場である (図 1 参照)。

返還跡地の約 6 割は並里区の区有地であったが、区はそのうちの $40 \%$ 金武町に売却し た。そして残りの $60 \%$ を町への賃貸とした。並里区は、ギンバル訓練場において年間約 9,000 万円程度の軍用地料を得ていたが、売却後、町は年間約 2,000 万円の賃貸料を並里区 に支払うという。算定はほぼ軍用地料と同じ比率であった。そして、町は海外の事業者と 100 年 (半永久) 賃貸契約を結び、半永久的に賃貸料が入る仕組みを確立した。この事業の 他の跡地利用との際立った違いは、金武町が土地を購入あるいは賃貸し、金武町の主導で 土地が使えるシステムを確立したことであった。並里区を含めた地権者にとっても、基地 返還後も収入が途絶えない巧みなシステムを構築できたということができよう [難波, $2015: 14]$ 。

今回のこの事業は、島田懇事業や北部振興対策事業以外にも、「沖縄北部連携促進特別 振興対策特定開発事業」など、開発費は総計で約 150 億円にのぼる国の補助金を投じて行 われる [難波, 2015：14]。

\section{7. 過剰開発をめぐる県と自治体 (市町村) の役割}

以上で見たように、沖縄の軍用跡地再開発調査から、過剰開発をめぐる自治体の役割と して、以下 3 点の知見を整理しておこう。

まず、第 1 が、軍用跡地再開発における公共事業と民間活力の利用の問題である。利益 を最優先する民間活力を利用すれば過剰開発は発生しないという議論もあろう。跡地再開 発は、再開発計画に沿って実行される。計画は一般的に私的財産の社会的拘束性の容認な しには実行されえない。他方で、民間活力の利用は、計画性が担保できないことがある。 すでに利益装置化した軍用地は、跡地再開発においてその対価として軍用地主に軍用地料 相当の収入を要求させるのである。今回の事例では、公的資金によって、跡地の買取りと 賃貸が同時に行われた。軍用地料の代わりとなる一時的所得と半永久的な地代を公的資金 によって確保することによって、基地の移設も再開発事業も成立させたのである。そし て、北部振興対策事業によって、村は野球場建設という公共事業もやり遂げた。ただ、公 共事業でもつて葛藤を除去しようとすれば、そこに自ずと過剩開発が発生するのである。 だが、このようなハコモノ事業が、果たして沖䋲県民の生活の質の向上をもたらしただろ うか。一部の軍用地主だけに利益が集中するような跡地再開発は、もちろん行うべきでは ないが、沖縄の自治体に最も要求される役割は、他との差異化を強調できる民間活力の利 用 ${ }^{6)}$ ではなかろうか。

第 2 は、過剰開発に対する県と自治体の関係の問題である。今回の事例を、政策過程論 
の政策波及 [伊藤, $2002 ： 37-38]$ という論理でとらえることも可能であろう。つまり、あ る政策が自治体に順次採用され、自治体間に広がる現象である。沖縄県は過剰開発を止め ることができるか。現実的には、個々の自治体に財源があれば、県全体としての過剰開発 を止めるのは難しいだろう。沖縄県は、嘉手納飛行場以南について、21世紀ビジョンを踏 まえて「中南部都市圈駐留軍用地跡地利用広域構想」を策定した [難波, $2015 ： 3]$ 。た だ、コンペによるこの都市広域構想も自治体担当者の眼には懐疑的に映る。県の構想にど れほどの拘束力があるのだろう。県と自治体は基本的には対等な関係にある。島田懇事業 や北部振興対策事業の実施によって、自治体と国が直接の太いパイプをもつことも、県と 自治体関係における沖縄社会特有の要因のひとつである。野球場やサッカー場の計画も、 自治体と国の直接交渉によって採択され補助されてきたのだ。

そして最後に、沖縄振興一括交付金についてである。この制度が地方自治にとつて画期 的なできごとであったことはすでに述べた。年間約 1,500 億円の国家の予算を 10 年間、沖 縄県の裁量で自由に事業を決定することができるようになつた。すなわち、この交付金に 限って言えば、県による市町村に対する事業へのリードが可能になつたのである。鉄道の 整備計画や 40 年間手つかずの軍用跡地の購入、普天間基地の先行土地購入など、今まで 行えなかった跡地利用計画が次々実行可能になる。ここに、全国の都道府県に先駆けて沖 縄県が国から勝ち取った交付金の意味は非常に大きい。ただ、これもまた「なぜ沖縄県に だけ特別に」という全国の自治体からの声がすでに上がっている。今後も一括交付金を活 用した過剰開発が発生しないか注視する必要があるだろう。

本稿は、ここまで軍用跡地再開発をめぐる自治体の役割について論じてきた。米軍基地 の存在は、沖縄県全域にわたつて多大なる影響を及ぼし続けてきた。そして、撤去後も 人々に影響を与え続ける。私は、これからもなお米軍基地と沖縄地域社会の展開と動向を 見守り続けるであろう。

\section{註}

1）くいなエコ・スポレク公園ウェブページ (http://ekospo.com/) など参照。国頭村役場の説明 では、野球場は年に 1 度 2 月にプロ野球の 2 軍キャンプでスター選手の卵が来村するだけで、 住民も満足していると説明する。しかし、2月のプロ野球キャンプの時期に、 7 球団が同時に 沖縄本島でキャンプができるだけの野球場があるという現実は、過剩というほかないであろ う。

2）島田䭒とは、「沖縄県米軍基地所在自治体活性化特別事業」の通称である。SACO 最終報告 とほぼ同時期の 1996 (平成 8) 年、橋本龍太郎政権下の梶山静六官房長官の私的な諮問機関と して、慶応大学の島田晴雄教授を座長とした「沖縄米軍基地所在自治体に関する懇談会 (沖縄 懇談会)」が開かれ、その懇談会による提言による事業であるために、そう呼ばれる。また、 北部振興事業とは、2004年の閣議決定「普天間飛行場の移設に関する政府方針」に基づいて設 置された「北部振興協議会」並びに「移設先及び周辺地域振興協議会」の方針による事業のこ とである [難波, $2015 ： 14$ ] 
3）ジェントリフィケーションとは、高級住宅化と訳されることもあるが、「高収入の住民があ る特定の都市内部地域（特にインナーシティに顕著に見られる）へ流入すること」を指す。重 要なのは、ジェントリフィケーションは、所得上の上方向への住民の入れ替えが起こることで ある [難波, 2000：91]。

4）内閣府沖縄総合事務局は、1972 年本土復帰と同時に、沖縄の振興開発を効率的に進めること を目的として、沖縄開発庁の地方支部局として設置され、2001年省庁再編の際に内閣府の地方 支分部局となつた。ダム、道路、港湾、空港等の社会資本の整備、農林水産業の基盤整備等の 公共事業のほか、財務省、農林水産省、経済産業省、国土交通省等の地方支分部局の業務を行 う国の総合出先機関である。

5）ここでいう区は、いわゆる地方自治法上の地域自治区のことではなくて、自治会・町内会に 相当する任意の団体を指す。沖縄県で区制が敷かれていた当時の名残ではなかろうか。

6）地域権力構造論的に言えば、この事例は基地の移設や町内に高度医療施設ができるという大 きな政策の中で、野球場建設という公共事業を顕在化させない (争点を見せない) バックラッ クの「非決定の権力」の構造が働いたとも考えられるが、公共事業とは別の開発を顕在化させ なかつた点については、現地で見出すことはできなかった。人口の小さな町村で、非争点化す ることは困難ではなかろうか。

\section{文献リスト}

青木康容, 2010,「沖縄の振興計画と地域開発」『佛教大学社会学部論集』第51号, 95-110頁 ， 2011,「沖縄の振興計画と地域開発 (2)」『佛教大学社会学部論集』第52 号, 69-84頁

福田 毅, 2003,「沖縄米軍基地の返還一SACO 合意の実施状況を中心に一」『レファレンス』平 成 15 年 10 月号, 国立国会図書館

伊藤修一郎， 2002, 『自治体政策過程の動態一政策イノベーションと波及一』慶應義塾大学出版会 ケント・E・カルダー, 武井楊一訳, 2008 , 『米軍再編の政治学：駐留米軍と海外基地のゆくえ』 日本経済新聞出版社

神谷国弘，1997，「老朽密集市街地の再開発をめぐる日独比較」中野三郎監修『人間と地域社会』 学文社

川瀬光義, 2013, 『基地維持政策と財政』日本経済評論社

来間泰男, 1998, 『沖縄経済の幻想と現実』日本経済評論社

$$
\text { , 2012, 『沖縄の米軍基地と軍用地料』がじゅまるブックス } 4
$$

林 博志, 2010, 宮本憲一・川瀬光義編『沖縄論一平和・環境・自治の島へ一』岩波書店

真喜屋美樹, 2007,「沖縄における軍事基地の跡地利用開発の検証一那覇市、北谷町、読谷村の 事例から一」,『アジア太平洋研究科論集』13号、早稲田大学大学院アジア太平洋研究 科, 169-194頁

\section{—, 2010, 「米軍基地の跡地利用開発の検証」、宮本憲一・川瀬光義編『沖縄論一平和・}

環境・自治の島へ一』岩波書店

南裕一郎, 2014, 「駐留軍用地の跡地利用一沖縄県金武町・ギンバル訓練場の事例一」平成 25-27年度科研費助成事業（基盤研究 (C) ) 研究成果中間報告書第 1 輯『沖縄振興の計画 と現実一返還跡地再開発をめぐる合意形成と公共性一』

内閣府沖縄総合事務局総務部跡地利用対策課「跡地利用の推進 跡地カルテ」ホームページ (http://atochi.ogb.go.jp/htdocs/) 2013年 
仲地 博, 1990, 「軍事基地利用の歴史・現状・課題」『大田昌秀教授退官記念論文集 沖縄を考 える』

難波孝志，2000，「ジェントリフィケーション」富田英典・森谷健編著『落ち着かない〈私〉と 〈社会〉』福村出版 : 87-102

一, 2005, 「地域デザインとその課題」瀧本佳史編『地域計画の社会学』昭和堂 : 109-128

—, 2013, 「沖縄の軍用地におけるコモンズの諸問題一杣山の軍用地料分収金をめぐる諸 相一」『大阪経大論集』第 63 巻第 5 号, 大阪経大学会 : 27-45

—, 2015, 「沖縄返還跡地再開発論へ向けた素材考察一軍用地と沖縄地域社会一」『大阪経 大論集』第 65 巻第 5 号, 大阪経大学会 : 1-18

沖縄県，2013，『沖縄の米軍基地 平成 25 年 3 月』沖縄県知事公室基地対策課

—, 2014, 『沖縄の米軍及び自衛隊基地（統計資料集）平成 26 年 3 月』沖縄県知事公室基地 対策課

沖縄県金武町，1991，『金武町と基地』沖縄県金武町企画開発課

沖縄夕イムス社編, 1997, 『127万人の実験』沖縄夕イムス社

琉球新報社, 2012,『ひずみの構造 基地と沖縄経済』新報新書

重森 暁，2000，「沖縄経済の自立的発展と県財政」宮本憲一・佐々木雅幸編『沖縄：21世紀へ の挑戦』岩波書店

島袋 純, 2014, 『「沖縄振興体制」を問う一壊された自治とその再生に向けて一』法律文化社 高橋明善, 1995,「基地の中での農村自治と地域文化の形成」山本・高橋・蓮見編『沖縄の都市 と農村』東京大学出版会

澈本佳史・青木康容，2014a，「軍用地料の「分収金制度」(4) - 「砂糖」と「海外移民」・「接収」 から「返還」へ一」『佛教大学社会学部論集』第58号, 125-148頁 ，2014b，「軍用地料の「分収金制度」(5) - 「軍用跡地利用計画」の展開一」 『佛教大学社会学部論集』第59号, 49-67頁

なお、本稿は、JSPS科研費「沖縄振興の計画と現実一返還跡地再開発をめぐる合意形成と公 共性一」(課題番号25380719) 代表者 難波孝志による研究成果である。

(なんば たかし／大阪経済大学情報社会学部教授) （原稿受付 2014 年 12 月 7 日 掲載決定 2015 年 6 月 5 日） 